\title{
SOLUTIONS FOR PROMOTING THE DEVELOPMENT OF VALUE ENGINEERING IN THE VIETNAMESE CONSTRUCTION INDUSTRY
}

\author{
VIET THANH NGUYEN ${ }^{1}$, SOO-YONG KIM ${ }^{2}$, VAN TRUONG LUU ${ }^{3}$ \\ ${ }^{1}$ Department of Civil Engineering, Industrial University of Ho Chi Minh City, Vietnam, \\ ${ }^{2}$ Department of Civil Engineering, Pukyong National University, Busan 48513, Korea, \\ ${ }^{3}$ Department of Civil Engineering, International University-VNU HCMC, Vietnam;
}

nguyenthanhviet@iuh.edu.vn,kims@pknu.ac.kr,van.lt@hcmiu.edu.vn

\begin{abstract}
Nowadays, Value Engineering (VE) is being widely practiced in many countries around the world. However, its concepts and applications do not seem to be well embraced in the Vietnamese construction industry. This study aims to seek solutions for promoting the development of VE in the Vietnamese construction industry. Most of the previous studies gave solutions in deficiencies and lack of analysis. On the basis of literature review and interviews with experts during the pilot test of the study at the initial stage, fifteen solutions were identified. A questionnaire survey was then conducted to rate the effective degree of the fifteen solutions. This study revealed six most effective solutions that should be taken with first priorities to promote the VE development. Additionally, the factor analysis method was applied to investigate the correlation effects of the solutions, which resulted in four core factors representing the solutions, namely, positive interest from government and construction stakeholders; education about VE; presence of VE organizations in the construction industry; and interaction with the outside world. The findings of the study are expected to bring the most effective solutions to promote the development of VE in the Vietnamese construction industry.

Keywords. construction industry, value engineering, value management, Vietnam.
\end{abstract}

\section{INTRODUCTION}

Value Engineering (VE) is also known as Value Management (VM) or Value Analysis (VA) [1]. VE is a systematic, multi-disciplinary and structured methodology. It identifies opportunities to remove unnecessary costs, to improve the value and optimize the life cycle cost of a facility while assuring that quality, reliability, performance, and other critical factors will meet or exceed the customer's expectations [2]. The origin of VE was conceived in the early 1940s by Lawrence D. Miles when he found ways to alleviate the material shortage problem in production of General Electric company during World War II [1]. The VE technique was subsequently introduced into construction by the US and the Army Corps of Engineers circa 1963. Outside the US, VE practices and applications were introduced in Japan, Italy, Australia and Canada - all during the 1970s [3]. In 1985, the association for VE practitioners was established, called as Society of American Value Engineers (SAVE) [4].

Nowadays, VE is being widely applied in many countries in the world. However, concepts and applications of VE do not seem to be well accepted in the construction industry of the majority of developing countries. In Malaysia and China, for example, VE is still its infancy and it has not been wellaccepted [5], [6]. VE is rarely applied in the Southeast Asia construction industry [3]. It is also less widely practiced in South Africa [7]. Malla [8] found that concept of VM is very much new in Nepal. The practice of VE in Myanmar and Nigerian construction is very slow and its term is not popular among construction professionals [9], [10]. In Vietnam, there is some evidence of VE process applications in construction projects, nevertheless it is still not so popular. VE in Vietnam is regarded as developing in the infant stage [11]. In fact, very few Vietnamese construction companies have adopted the VE process to reduce costs and enhance quality. The majority of owners are still unfamiliar with the concept of VE. VE has been applied mainly by foreign consulting firms or Engineering Procurement Construction (EPC) contractors, such as Japanese and Korean firms [11].

In summary, the VE methodology seems to be very new and to be rarely applied in the construction sector of the majority of developing countries. There are always some certain roadblocks hindering the 
application of VE such as lack of local guidelines and legislation about VE, lack of knowledge and awareness of VE, inherent difficulties in VE workshop, and so on. Therefore, it is really necessary to provide solutions for overcoming difficulties and promoting the VE development in the construction industry of developing countries in general and of Vietnam in particular. The objectives of this paper are to identify solutions for promoting the VE development in the Vietnamese construction industry and investigate the underlying relationships between them.

\section{LITERATURE REVIEW}

Some researchers have given solutions to promote the VE development in the construction industry. Shen [12] found that some actions should be taken with first priorities in Hong Kong such as introducing a VE culture in clients organizations, consultancy firms and contractors, setting up a standard and a certification program to clarify VE theories and practices, and seeking continuous support from the government to promote VE in all large capital projects in the public sector. And in order to facilitate the above actions, a number of good quality handbooks and guideline with local context should be produced, and more awareness seminars should be arranged. Sik and Fong [13] also conducted a study in Hong Kong and revealed that with regard to promotion of the VE development, the marketing effort will probably increase. It is believed that all VE societies, governments and industries need to share responsibility for promotion. In VE societies, increasing awareness, certification and training are what most people predict to be the main focuses in the future. Shen and Liu [14] studied applications of VE in the construction industry in China. They found that many actions should be taken to promote its development. Some strategic issues were recommended as follows: a successful application framework in the context of construction should be developed; communication with the outside world should be enhanced; and continuing government support should be sought.

Perera and Karunasena [15] proposed some directions for the improvement of usage of VE in Sri Lanka; those were, conducting seminars, workshops and educating the industry, conducting short courses on VE, implementing some regulation for application of VE, introducing any regulatory body to observe and regulate the application of VE, and following up and getting the knowledge from other developing countries how they are successful in application of VE. Cheah and Tings' study [3] pointed out that many hurdles still stand in the way for VE practices to flourish in the Southeast Asia construction industry, therefore, governments and building/construction authorities should play a lead role in promoting VE. Specifically, incentives to apply VE should be built within the provisions of public contracts. It is also necessary to build up case precedence and form a database showing success and failure rates of VE applications. In Malaysia, Lai [16] gave some recommendations to improve the awareness and usage of VE in the construction industry. First, related organizations should establish more seminars, training program to introduce what is about VE and its application. Second, the government needs to encourage and promote the use of VE. Third, top management of any organization needs to support and apply it in their organization. Next, institute of VE should play an important role to use any marketing strategies to promote VE in the industry. Lastly, a local VE implementation guideline should be established.

Latief and Untoro K [4] recommended that the Public Works Department in Indonesia should create and determine detailed guidelines and regulation about VE implementation for all projects in its division, conduct trainings and certification, provide a qualified team for applying VE analysis. Li and Ma [6] suggested some solutions to promote VE development in China such as strengthening government oversight and guidance, strengthening publicity and education, training of personnel, and strengthening cooperation with foreign counterparts. Lately, Fard et al. [17] identified the factors which were essential to improve VE utilization in Iran were the importance of adding VE change proposals clause in the contract document, the necessity of Malla [8] the presence of a VE certified personnel in design team, the necessity of providing VE training opportunities for experts and students, and the necessity of making clients more demanding and knowledgeable of VE. proposed some solutions to promote the VE application in the Nepalese construction industry such as incentive clause for VE re-proposal in contract document, commitment from top management, and forming a VE team with experienced members. Aduze [10] made some recommendations in the Nigerian construction industry as follows: there should be a government legislation to back-up the implementation of VE practice; government department and 
agencies should also carry out VE's pilot studies on public works projects to explore its applicability; professional bodies should arrange VE seminars; and regular workshops should be held to improve the professional competence of members.

Based on the literature review, it can be concluded that solutions found from each of the previous studies were not enough. Moreover, there was a lack of analysis on the solutions such as rating the effectiveness of the solution or uncovering the underlying relationship among them. This study attempts to fill these gaps.

\section{METHODOLOGY}

A survey questionnaire was designed to gather views from industrial practitioners in Vietnam. The development of the survey questionnaire used in this study was supported by the literature review. A preliminary set of solutions was collected from the literature review and presented in the pretest questionnaires. A pilot study was then carried out to validate the questionnaire with five experts (three project managers, two engineering managers) who had experience in VE practice. The experts were asked to comment on the readability, comprehensiveness, and accuracy of all questions in the pretest questionnaires. Moreover, they were also asked to remove any solutions perceived as being inappropriate and add other solutions perceived as being necessary. According to the experts' comments, there were some additional solutions and it was necessary to have some minor adjustments in structure of the questionnaire and wording in questions. As a result of the literature review and pilot test, fifteen solutions were identified as shown in Table 1.

The target respondents of the questionnaire survey included contractors, designers, consultants, and owners who are mainly involved in the VE workshops. Respondents were asked to rate the effective degree of the fifteen solutions according to a five -point Likert scale $(1=$ not effective, $2=$ less effective, $3=$ averagely effective, $4=$ strongly effective, and $5=$ extremely effective). A total of 200 questionnaires were distributed to respondents. Out of 200 questionnaires distributed, 76 valid responses were received, representing the response rate of $38 \%$. This response rate was acceptable compared with the norm of 20 $30 \%$ with most questionnaire surveys in the construction industry [18].

The valid replies consisted $26.3 \%$ of owners, $34.2 \%$ of contractors, $22.4 \%$ of designers, and $17.1 \%$ of consultants from the overall respondents. The number of respondents with experience from 5 to 10 years, and above 10 years was $52.6 \%, 35.5 \%$, respectively. The respondents with less than 5 years of experience accounted for only $11.9 \%$. These proportions of years of experience imply that the collected data are relatively reliable and valuable.

The valid data set collected from the questionnaires was then analyzed on Statistical Package for Social Sciences (SPSS version 20) software. First, the reliability of the five-point scale used to measure the solutions was determined using Cronbach's coefficient alpha. Subsequently, the "mean score" method was used to rank the solutions. Finally, factor analysis was conducted to derive the interrelationships among the solutions.

Table 1. Fifteen solutions for promoting the VE development.

\begin{tabular}{|c|l|l|}
\hline Codes & \multicolumn{1}{|c|}{ Solutions } & \multicolumn{1}{|c|}{ References } \\
\hline S1 & $\begin{array}{l}\text { Organizing VE training courses to improve the } \\
\text { skills and competence of personnel in practicing } \\
\text { the VE procedure }\end{array}$ & $\begin{array}{l}\text { Sik and Fong [13], Lai [16], Latief and Untoro K [4], } \\
\text { Li and Ma [6], Fard et al. [17] }\end{array}$ \\
\hline S2 & $\begin{array}{l}\text { Seeking top managements' support of firms for } \\
\text { implementing VE in their organizations }\end{array}$ & Lai [16], Malla [8] \\
\hline S3 & $\begin{array}{l}\text { Introducing foreign certification and collaborating } \\
\text { with international VE organizations to train more } \\
\text { VE experts }\end{array}$ & Li and Ma [6] \\
\hline
\end{tabular}




\begin{tabular}{|c|c|c|}
\hline Codes & Solutions & References \\
\hline S4 & $\begin{array}{l}\text { The need of having a number of good VE teams } \\
\text { and facilitators to conduct VE studies }\end{array}$ & Latief and Untoro K [4], Fard et al. [17], Malla [8] \\
\hline S5 & $\begin{array}{l}\text { Building up a database system showing success } \\
\text { and failure of VE applications from the previous } \\
\text { projects }\end{array}$ & Cheah and Ting [3] \\
\hline S6 & $\begin{array}{l}\text { Establishing companies specialized in consulting } \\
\text { and implementing VE studies }\end{array}$ & Experts' opinion \\
\hline S7 & $\begin{array}{l}\text { Organizing regularly VE seminars, workshops to } \\
\text { disseminate and share knowledge and experience } \\
\text { about VE }\end{array}$ & $\begin{array}{l}\text { Shen [12], Perera and Karunasena [15], Lai [16], } \\
\text { Aduze [10] }\end{array}$ \\
\hline S8 & $\begin{array}{l}\text { Putting VE knowledge into undergraduate courses } \\
\text { and postgraduate courses }\end{array}$ & Experts' opinion \\
\hline S9 & $\begin{array}{l}\text { Construction agencies should play an important } \\
\text { role in the dissemination and application of VE }\end{array}$ & $\begin{array}{l}\text { Sik and Fong [13], Cheah and Ting [3], Lai [16], Li } \\
\text { and Ma [6] }\end{array}$ \\
\hline S10 & $\begin{array}{l}\text { Seeking continuous the government's support to } \\
\text { promote VE applications in all large capital } \\
\text { projects in the public sectors }\end{array}$ & Shen [12], Shen and Liu [14], Lai [16], Aduze [10] \\
\hline S11 & $\begin{array}{l}\text { Introducing VE methodology in organizations } \\
\text { (owners, consultants, designers, contractors) by } \\
\text { carrying out a VE study as a live example of its } \\
\text { success to change the negative viewpoint of the } \\
\text { organizations towards VE }\end{array}$ & Shen [12], Fard et al. [17] \\
\hline S12 & $\begin{array}{l}\text { Carrying out actively exchanges with foreign } \\
\text { countries and learning from their experiences in } \\
\text { promoting the development of } \mathrm{VE}\end{array}$ & $\begin{array}{l}\text { Shen and Liu [14], Perera and Karunasena [15], Li } \\
\text { and Ma [6] }\end{array}$ \\
\hline S13 & $\begin{array}{l}\text { Promulgation of appropriate legislation relating to } \\
\text { VE implementation }\end{array}$ & $\begin{array}{l}\text { Perera and Karunasena [15], Latief and Untoro K } \\
\text { [4], Cheah and Ting [3], Fard et al. [17], Malla [8], } \\
\text { Aduze [10] }\end{array}$ \\
\hline $\mathrm{S} 14$ & Establishing the VE association in Vietnam & Experts' opinion \\
\hline $\mathrm{S} 15$ & $\begin{array}{l}\text { A number of good quality handbooks and } \\
\text { guidelines with local context should be published }\end{array}$ & $\begin{array}{l}\text { Shen [12], Shen and Liu [14], Lai [16], Latief and } \\
\text { Untoro K [4] }\end{array}$ \\
\hline
\end{tabular}

\section{DATA ANALYSIS AND DISCUSSION}

\subsection{Ranking of the Solutions}

A Cronbach's alpha of 0.846 for the 15 solutions was computed, which is above the recommended threshold value of 0.7 , confirming the reliability of the five-point scale measurement [19].

Table 2 shows the ranking of the 15 solutions. The standard deviation values of the solutions are less than one, which reflects some consensus among the respondents. The mean scores of the solutions range from 3.28 (S5) to 4.22 (S7). It can be seen that these mean scores are higher than the mid-point score of 3 on a five-point Likert scale. This can be indicated that the 15 solutions are effective for promoting the VE development. The six solutions, namely, organizing regularly VE seminar, workshops to disseminate and share knowledge and experience about VE (S7, mean value 4.22); putting VE knowledge into undergraduate courses and postgraduate courses (S8, mean value 4.13); construction agencies should play 
an important role in the dissemination and application of VE (S9, mean value 4.12); a number of good quality handbooks and guidelines with local context should be published (S15, mean value 4.11); organizing VE training courses to improve the skills and competence of personnel in practicing the VE procedure (S1, mean value 4.08); seeking top managements' support of firms for implementing VE in their organizations (S2, value mean 4.01) are very highly ranked by all the respondents. The means of all these six solutions are greater than 4 - equivalent to "very effective" on a five-point Likert scale. Hence, they are considered to be solutions that should be taken with first priorities.

Table 2. Ranking of the solutions.

\begin{tabular}{|c|c|c|c|c|}
\hline Codes & Solutions for promoting the VE development & Mean & $\begin{array}{l}\text { Standard } \\
\text { deviation }\end{array}$ & Ranking \\
\hline S7 & $\begin{array}{l}\text { Organizing regularly VE seminars, workshops to disseminate and share } \\
\text { knowledge and experience about VE }\end{array}$ & 4.22 & 0.67 & 1 \\
\hline S8 & $\begin{array}{l}\text { Putting VE knowledge into undergraduate courses and postgraduate } \\
\text { courses }\end{array}$ & 4.13 & 0.53 & 2 \\
\hline S9 & $\begin{array}{l}\text { Construction agencies should play an important role in the } \\
\text { dissemination and application of VE }\end{array}$ & 4.12 & 0.56 & 3 \\
\hline S15 & $\begin{array}{l}\text { A number of good quality handbooks and guidelines with local context } \\
\text { should be published }\end{array}$ & 4.11 & 0.81 & 4 \\
\hline S1 & $\begin{array}{l}\text { Organizing VE training courses to improve the skills and competence } \\
\text { of personnel in practicing the VE procedure }\end{array}$ & 4.08 & 0.54 & 5 \\
\hline S2 & $\begin{array}{l}\text { Seeking top managements' support of firms for implementing VE in } \\
\text { their organizations }\end{array}$ & 4.01 & 0.50 & 6 \\
\hline S14 & Establishing the VE association in Vietnam & 3.95 & 0.63 & 7 \\
\hline S13 & $\begin{array}{l}\text { Promulgation of appropriate legislation relating to the VE } \\
\text { implementation }\end{array}$ & 3.88 & 0.80 & 8 \\
\hline $\mathrm{S} 11$ & $\begin{array}{l}\text { Introducing VE methodology in organizations (owners, consultants, } \\
\text { designers, and contractors) by carrying out a VE study as a live } \\
\text { example of its success to change the negative viewpoint of the } \\
\text { organizations towards VE }\end{array}$ & 3.80 & 0.73 & 9 \\
\hline S3 & $\begin{array}{l}\text { Introducing foreign certification and collaborating with international } \\
\text { VE organizations to train more VE experts }\end{array}$ & 3.78 & 0.58 & 10 \\
\hline S4 & $\begin{array}{l}\text { The need of having a number of good VE teams and facilitators to } \\
\text { conduct VE studies }\end{array}$ & 3.74 & 0.62 & 11 \\
\hline S6 & $\begin{array}{l}\text { Establishing companies specialized in consulting and implementing VE } \\
\text { studies }\end{array}$ & 3.63 & 0.76 & 12 \\
\hline $\mathrm{S} 10$ & $\begin{array}{l}\text { Seeking continuous the government's support to promote VE } \\
\text { applications in all large capital projects in the public sectors }\end{array}$ & 3.53 & 0.70 & 13 \\
\hline $\mathrm{S} 12$ & $\begin{array}{l}\text { Carrying out actively exchanges with foreign countries and learning } \\
\text { from their experiences in promoting the development of VE }\end{array}$ & 3.42 & 0.55 & 14 \\
\hline S5 & $\begin{array}{l}\text { Building up a database system showing success and failure of VE } \\
\text { applications from the previous projects }\end{array}$ & 3.28 & 0.64 & 15 \\
\hline
\end{tabular}

\subsection{Factor Analysis}

The factor analysis method was used to investigate the underlying relationships between the solutions. The reliability of the factor model was checked with the communalities of each solution. The item S4 "the need of having a number of good VE teams and facilitators to conduct VE studies" and the item S5 "building up a database system showing success and failure of VE application from previous projects" are eliminated because their communalities are less than 0.5 , which does have enough explanatory value [19]. Communalities of all the other solutions are found to be much greater than 0.584 that signifies that the factor model is reliable in this study. The adequacy of the survey data was examined by conducting the Kaiser-MeyerOlkin (KMO) test and the Bartlett's test of specificity. The result of the $\mathrm{KMO}$ statistic is 0.779 and the sphericity test is significant with its associated p-value as 0.000 . Therefore, the data are appropriate for factor analysis. 
The factor analysis was conducted by Principle Component Analysis and Varimax Rotation. Four factors were extracted with eigenvalues greater than 1 according to Kaiser's criteria. These four factors explained $68.7 \%$ of the total variance in the data, which is higher than the $60 \%$ recommended by Hair et al. [19]. All factor loadings of the solutions are greater than 0.5 , which is considered in contributing to the interpretation of the factor [19]. Based on an examination of inherent relationships among the solutions under each of the factors, the four factors are assigned a new name for further discussion. Table 3 shows the results of the factor analysis. The associated explanations regarding four factors are provided in the following sections.

Table 3. The results of factor analysis.

\begin{tabular}{|c|c|c|c|c|}
\hline Factor of solutions & $\begin{array}{c}\text { Variance } \\
\text { explained } \\
(\%) \\
\end{array}$ & Codes & Solutions & Factor loading \\
\hline \multirow{5}{*}{$\begin{array}{l}\text { Factor 1: Positive interest from } \\
\text { government and construction } \\
\text { stakeholders }\end{array}$} & \multirow{5}{*}{22.538} & $\mathrm{~S} 2$ & $\begin{array}{l}\text { Seeking top managements' support of firms } \\
\text { for implementing VE in their organizations }\end{array}$ & 0.800 \\
\hline & & S13 & $\begin{array}{l}\text { Promulgation of appropriate legislation } \\
\text { relating to the VE implementation }\end{array}$ & 0.726 \\
\hline & & $\mathrm{S} 10$ & $\begin{array}{l}\text { Seeking continuous the government's } \\
\text { support to promote VE applications in all } \\
\text { large capital projects in the public sectors }\end{array}$ & 0.693 \\
\hline & & S9 & $\begin{array}{l}\text { Construction agencies should play an } \\
\text { important role in the dissemination and } \\
\text { application of VE }\end{array}$ & 0.675 \\
\hline & & $\mathrm{S} 11$ & $\begin{array}{l}\text { Introducing VE methodology in } \\
\text { organizations (owners, consultants, } \\
\text { designers, and contractors) by carrying out } \\
\text { a VE study as a live example of its success } \\
\text { to change the negative viewpoint of the } \\
\text { organizations towards VE }\end{array}$ & 0.666 \\
\hline \multirow{4}{*}{ Factor 2: Education about VE } & \multirow{4}{*}{21.432} & S7 & $\begin{array}{l}\text { Organizing regularly VE seminars, } \\
\text { workshops to disseminate and share } \\
\text { knowledge and experience about VE }\end{array}$ & 0.783 \\
\hline & & S8 & $\begin{array}{l}\text { Putting VE knowledge into undergraduate } \\
\text { courses and postgraduate courses }\end{array}$ & 0.755 \\
\hline & & $\mathrm{S} 15$ & $\begin{array}{l}\text { A number of good quality handbooks and } \\
\text { guidelines with local context should be } \\
\text { published }\end{array}$ & 0.732 \\
\hline & & S1 & $\begin{array}{l}\text { Organizing VE training courses to improve } \\
\text { the skills and competence of personnel in } \\
\text { practicing the VE procedure }\end{array}$ & 0.689 \\
\hline \multirow{2}{*}{$\begin{array}{l}\text { Factor 3: Presence of VE } \\
\text { organizations in the } \\
\text { construction industry }\end{array}$} & \multirow[t]{2}{*}{12.465} & S6 & $\begin{array}{l}\text { Establishing companies specialized in } \\
\text { consulting and implementing VE studies }\end{array}$ & 0.859 \\
\hline & & $\mathrm{S} 14$ & Establishing the VE association in Vietnam & 0.746 \\
\hline \multirow{2}{*}{$\begin{array}{l}\text { Factor } 4 \text { : Interaction with the } \\
\text { outside world }\end{array}$} & \multirow[t]{2}{*}{12.265} & $\mathrm{~S} 12$ & $\begin{array}{l}\text { Carrying out actively exchanges with } \\
\text { foreign countries and learning from their } \\
\text { experiences in promoting the development } \\
\text { of VE }\end{array}$ & 0.858 \\
\hline & & S3 & $\begin{array}{l}\text { Introducing foreign certification and } \\
\text { collaborating with international VE } \\
\text { organizations to train more VE experts }\end{array}$ & 0.840 \\
\hline
\end{tabular}




\subsubsection{Positive Interest from Government and Construction Stakeholders}

This factor comprises five solutions and accounts for the greatest variance (22.538\%) among all the factors. This factor emphasizes the importance of government and construction stakeholders in promoting the VE development. Experiences in many other countries showed that the prosperity and development of VE applications rely heavily on government's support [12]. Because the government did not take the first step, the private sector also lacks supporting this method [20]. The government support is a necessary driving force in the initial stages of VE development [14]. The government should promulgate legislation relating to VE implementation such as putting the VE study as a stage of the project stages and including it in the quality system or including a clause that entails conducting VE on the project before allocating a budget for it, allocating an incentive for organization that applies VE by sharing the cost savings, etc. Government legislation can force companies and organizations to apply VE for their betterment [13]. Too few construction projects applied VE is one of factors hindering the application of VE in the construction industry. In Vietnam, many construction projects are funded by government or state-owned companies, therefore persuading the government to increase the demand for VE in public projects is really necessary. Government department and agencies should foremost carry out VE's pilot studies on public works projects to explore its applicability.

In order to promote the development of VE, the marketing effort will be necessary. It is believed that all companies, organizations and the government need to share responsibility for promotion. Construction authorities should play an important role in the dissemination and application of VE. It is really necessary to introduce a VE culture in clients organizations, consultancy, designer firms, and contractors in the industry by improving awareness and applications among professionals and senior management in these firms and by offering assistance and training in organizing and managing successful VE studies. Introducing VE in organizations is also an active action to change negative viewpoints of the construction stakeholders about VE. "Seeking top managements' support of firms for implementing in their organizations" in this component reflects the top managements' significant influence on the development of VE. The top managements of firms or the decision-makers are the key people who have the right to decide most matters related to their organizations so seeking the top managements' support is a quite useful solution to push the VE development in the construction industry.

\subsubsection{Education about VE}

This factor explains $21.432 \%$ of the total variance in the data. The four solutions included in this factor are all related to education about VE and they are four of the six most effective solutions. This implies that the education about VE is very important that require immediate attention to promote the development of VE methodology. The comprehension or understanding level of VE technique and management is still low in the construction industry, therefore more efforts should be required to educate industrial practitioners and owners on various aspects of VE. Sik and Fong [13] showed that education about VE is seen as the one of the most important actions that could push VE forward. Education programs can provide a sound academic base as well as training up future generations of VE professionals [13]. Educational methods can include many ways from basic level to advanced level such as putting VE knowledge into undergraduate courses and postgraduate courses, publishing good quality handbooks and guidelines, organizing regularly VE seminars and workshops, and organizing VE training courses.

In universities, VE can be part of the broader curriculum and this is a good way to spread knowledge quickly. However, knowledge obtained can be just basic and theoretical as well as lack of practical applications. Zabych [21] stated that VE knowledge training at universities is inadequate, the main reason being the insufficient number of educational courses and educators. Practical experience plays a very important role. Practical experience is the major source of practical knowledge [13]. Hence, activities as organizing seminars, workshops and training courses should be increased. Moreover, the cooperation between universities and practitioners as VE experts should be encouraged to enhance the quality of VE training in the university environment. The seminars and workshops will explore ways of making the VE process more efficient, with the objective of making recommendations in support of VE studies with time constraints [22]. Organizing VE training courses will help practitioners improve the skills and competence in practicing the VE procedure, increase the number of qualified personnel with proper 
composition for each working unit in order to provide a suitable team for applying VE analysis in their works. Besides, a number of good quality handbooks and guidelines with local context should exist in the domestic construction industry to facilitate acquiring VE knowledge and ensure the application of VE procedure correctly.

\subsubsection{Presence of VE Organizations in the Construction Industry}

This factor consists of two solutions, namely, "establishing companies specialized in consulting and implementing VE studies" and "establishing the VE association". It explains $12.465 \%$ of the total variance in the data. The official presence of VE organization in the construction industry is really necessary. It lays basic foundation for VE growth and is also a sign of its existence. This promotes somewhat the development and application of VE methodology. Establishing the VE association demonstrates the affiliation and professionalism of professionals in the construction industry. Professionals should come together to support construction agencies, companies in disseminating VE knowledge and training more qualified personnel. Moreover, the VE association can collaborate with international VE organizations in order to publicize VE through training, certification, seminars, workshops, and other means of promotion. Very few construction companies apply VE procedure in their projects perhaps because they lack the qualified manpower to implement it and are unfamiliar with this approach. Hence, external consultants with VE expertise coming from companies specialized in consulting and implementing VE studies is necessary for VE services.

\subsubsection{Interaction with outside world}

This factor explains $12.265 \%$ of the total variance in the data and comprises two solutions, namely, "carrying out actively exchanges with foreign countries and learning from their experiences in promoting the development of VE" and "introducing foreign certification and collaborating with international VE organizations to train more VE experts". These two factors mention the need of interaction with the outside world. In Vietnam, local experience of VE application in construction is very limited. Regarding certification and training related to VE, the number of people having VE certification was still small. Hence, communication with the outside world should be enhanced. Communication with the outside world could allow Vietnam a shortcut to learn and adapt the overseas experience. Through a number of activities such as employing foreign VE experts as facilitators, holding annual international VE conferences and organizing short-term training courses lectured by foreign VE experts, collaborating to train more domestic VE experts, the VE development can quickly achieve success.

\section{CONCLUSIONS}

This paper performed a questionnaire survey that was to identify solutions for promoting the VE development and discover the underlying relationships between them. Fifteen solutions were identified through the literature and pilot test. All respondents agreed that "organizing regularly VE seminar, workshops to disseminate and share knowledge and experience about VE", "putting VE knowledge into undergraduate courses and postgraduate courses", "construction agencies should play an important role in the dissemination and application of VE", "a number of good quality handbooks and guidelines with local context should be published", "organizing VE training courses to improve the skills and competence of personnel in practicing the VE procedure", "seeking top managements" support of firms for implementing VE in their organizations" are the six most effective solutions and therefore they should be taken with first priorities. The factor analysis method discovered four factors representing the solutions: factor 1 represents positive interest from government and construction stakeholders; factor 2 represents education about VE; factor 3 represents presence of VE organizations in the construction industry; factor 4 represents interaction with the outside world.

The findings of the study could help the government, stakeholders, and companies in the construction industry get the most effective solutions and then give appropriate strategies for their organizations in promoting the application of VE. The study can be considered as a valuable additional contribution to the body of knowledge regarding the application of VE in the construction industry. 
Despite the achievement of the objectives, there is a limitation to this study. The study was conducted in context of Vietnam, therefore the findings may not be generalized to other geographical locations. However, the findings can be reference to many developing countries, as they face similar problems in terms of promoting the development of VE in the construction industry.

\section{ACKNOWLEDGMENT}

The authors would like to express their sincere gratitude to the industrial practitioners in Vietnam who have responded and contributed their valuable input in completing the survey questionnaires used in the study.

\section{REFERENCES}

[1] SAVE International (Society of American Value Engineers International). [Online]. Available: www.valueeng.org.

[2] A. J. Dell'Isola, Value engineering practical applications: for design, construction, maintenance, and operations, R. S. Means Company, United Stated of American, 1997.

[3] C. Y. J. Cheah, and S. K. Ting, Appraisal of Value Engineering in construction in Southeast Asia, International Journal of Project Management, vol. 23, no. 2, pp. 151 - 158, 2005.

[4] Y. Latief, and I. V. Untoro K, Implementation of Value Engineering in the Infrastructure Services of Indonesia's Public Works Department, SAVE International, vol. 32, no. 3, pp. 10 - 14, 2009.

[5] A. Jaapar, I. R. Endut, N. A. A. Bari, and R. Takim, The Impact of Value Management Implementation in Malaysia, Journal of Sustainable Development, vol. 2, no. 2, pp. 210 - 216, 2009.

[6] X. Li, and W. Ma, Appraisal of Value Engineering Application to Construction Industry in China, Y.Zang (Ed.): Future Wireless Networks and Information Systems, LNEE 144, pp. 303 - 311, 2012.

[7] P. Bowen, K. Cattell, P. Edwards, and I. Jay, Value Management practice by South African quantity surveyors, Facilities, vol. 28, no. 1/2, pp. $46-63,2010$.

[8] S. Malla, Application of Value Engineering in Nepalese Building Construction Industry, 2013. [Online]. Available: http://professionalprojectmanagement.blogspot . kr/2013/06/application-of-value-engineeringin.html.

[9] W. W. M. Phyo, and A. M. Cho, Awareness and Practice of Value Engineering in Myanmar Construction Industry, International Journal of Scientific Engineering and Technology Research, vol. 3, no. 10, pp. 2022 $2027,2014$.

[10] O. C. Aduze, A Study of the Prospects and Challenges of Value Engineering in Construction Projects in Delta and Edo States of Nigeria, MSc diss., Nnamdi Azikiwe University, 2014.

[11] N. T. Viet, and L. T. Van, Study on process of internal Value Engineering (VE) in construction projects in Vietnam, Review of Ministry of Construction in Vietnam, vol. 52, no. 7, pp. 68 - 71, 2013.

[12] Q. P. Shen, Value Management in Hong Kong's Industry: Lessons Learned, SAVE Int. Conf. SAVE International, Dayton, Ohio, 1997, pp. 260 - 265.

[13] P. Sik, and W. Fong, A critical appraisal of recent advances and future directions in value management, European Journal of Engineering Education, vol. 29, no. 3, pp. 377 - 388, 2004.

[14] Q. Shen, and G. Liu, Application of value management in the construction industry in China, Engineering, Construction and Architectural Management, vol. 11, no. 1, pp. 9 - 19, 2004. 
[15] S. Perera, and G. Karunasena, Application of Value Management in the Construction Industry of Sri Lanka, The Value Manager, vol. 10, no. 2, pp. 4 - 8, 2004.

[16] N. K. Lai, Value Management in Construction Industry, MSc diss., Technology University Malaysia, 2006.

[17] A. B. Fard, K. G. Rad, P. G. P. Sabet, and H. Aadal, Evaluating Effective Factors on Value Engineering Implementation in the Context of Iran, Journal of Basic and Applied Scientific Research, vol. 3, no. 10, pp. $430-436,2013$.

[18] A. Akintoye, Analysis of factors influencing project cost estimating practice, Construction Management and Economics, vol. 18, no. 1, pp. 77-89, 2000.

[19] J. F. Hair, W. C. Black, B. J. Babin, and R. E. Anderson, Multivariate data analysis, 7th Ed., Pearson Education, Upper Saddle River, NJ, 2010.

[20] C. M. Mazlan, The Challenges and Potential of Value Management In Local Construction, Faculty of Build Environment, UTM, pp. $610-611,1998$.

[21] M. N. Zabych, A proposal for VE college course training, SAVE Proceedings, 1994, pp. 83-86.

[22] K. Hunter, and J. Kelly, Efficiency in VM/VE Studies and the Pressure for Shorter Workshops, Value World Journal, SAVE International, USA, 2007.

\section{CÁC GIẢI PHÁP ĐẨY MẠNH SỰ PHÁT TRIỂn CỦA VALUE ENGINEERING TRONG NGÀंN XÂY DỨNG VIỆT NAM}

Tóm tắt. Ngày nay, Value Engineering (VE) đã được áp dụng phổ biến ở nhiều nước trên thế giới. Tuy nhiên, VE dường như chưa được chấp nhận rộng rãi trong ngành xây dựng Việt Nam. Nghiên cứu này nhằm mục đích tìm kiếm các giải pháp để thúc đẩy sự phát triển của VE. Dựa trên các nghiên cứu trước đây và phỏng vấn các chuyên gia, nghiên cứu này xác định được 15 giải pháp. Một cuộc khảo sát sau đó được tiển hành để đánh giá mức độ hiệu quả của 15 giải pháp. Nghiên cứu khám phá ra sáu giải pháp hiệu quả nhất nên được ưu tiên để thúc đẩy sự phát triển của $V E$ và bốn nhân tố đại diện cho các giải pháp đó là sự quan tâm tích cực của chính phủ và các bên liên quan, sự giáo dục về VE, sự có mặt của tổ chức VE trong ngành xây dựng, sự tương tác với thế giới bên ngoài. Những phát hiện của nghiên cứu này hy vọng sẽ mang lại các giải pháp hiệu quả nhất để đẩy mạnh sự phát triển của VE trong ngành xây dựng Việt Nam.

Từ khóa. ngành xây dựng, value engineering, value management, Việt Nam.

Ngày nhận bài: 29/09/2017

Ngày chấp nhận đăng: 28/12/2017

C 2017 Trường Đại học Công nghiệp thành phố Hồ Chí Minh 